\title{
A Case of Myelodysplastic Syndrome in an Adult with Down Syndrome: A Rare Observation of a Well-known Pediatric Disease
}

Down Sendromlu Erişkinde Myelodisplastik Sendrom: lyi Bilenen Bir Pediatrik Hastalığın Nadiren Görülmesi

(D) Harpreet Virk 1 , (D) Shano Naseem²

1 Postgraduate Institute of Medical Education and Research, Senior Resident, Department of Pathology, Chandigarh, India

2 Postgraduate Institute of Medical Education and Research, Department of Hematology, Chandigarh, India

To the Editor,

A 56-year-old man with Down syndrome (DS) presented with a fever for the previous 7 weeks. On evaluation he was found to have bicytopenia with hemoglobin $(\mathrm{Hb})$ of $87 \mathrm{~g} / \mathrm{L}$ and platelet count of $100 \times 10^{9} / \mathrm{L}$. Total leukocyte count was $5.9 \times 10^{9} / \mathrm{L}$. Even after an adequate trial of hematinics, the anemia persisted. Bone marrow examination revealed significant dysgranulopoiesis in $43 \%$ of neutrophils in the form of hypolobation, hypogranulation, ring forms, and pseudo-Pelger-Huet anomaly (Figures 1a-1c). No significant dyserythropoiesis or dysmegakaryopoiesis was noted. Bone marrow biopsy showed hypercellular marrow spaces with granulocytic hyperplasia; however, megakaryocytes and erythroid series were adequately represented. Fluorescence in situ hybridization (FISH) testing was performed, which revealed deletion of the $20 q 12$ locus in 140/200 (70\%) of nuclei examined (Figure 1d). It was negative for $-7 / 7 q$ deletion, $-5 / 5 q$ deletion, and trisomy 8 . The patient currently remains under observation with hematinic supplementation and close followup of blood counts.

The age of onset for myeloid neoplasms in children with DS is bimodal, peaking first in the newborn period and again at 3-6 years. However, this increased risk continues even into adulthood [1]. Pertaining to this increased risk, even minor but persistent cytopenias give rise to concerns regarding the possibility of underlying myelodysplastic syndrome (MDS) or marrow failure, or the potential for the development of myeloid leukemia. This has become important given the increasing life expectancy of adults with this disorder [2]. Although conditions like hypothyroidism, obesity, epilepsy, dementia, and Alzheimer's disease are known to become increasingly prevalent in individuals with DS in later life [3], myeloid leukemias in general and MDS in particular are relatively less common.

Deletion of the long arm of chromosome 20 (del20q) has been reported in 3\%-7\% of patients with MDS. Isolated del20q is associated with a low risk of progression to $A M L$, with good prognosis and overall prolonged survival [4]. Although this abnormality has been well documented in the MDS subpopulation, its prevalence in MDS associated with DS has not been described in the literature. McLean et al. studied 9 patients with DS with a median age of 41 years having clinical suspicion of MDS. In their cohort, multilineage dysplasia was observed in one case only. No acquired cytogenetic abnormality was seen in any of the cases [5].

Our patient had bicytopenia to begin with, with improvement in leukocyte and platelet counts after supportive care. However, his $\mathrm{Hb}$ was persistently low even after an adequate trial of hematinics. Morphological dysplasia was noted in a single lineage in the form of dysgranulopoiesis and FISH studies revealed deletion in $20 q$, which to our knowledge has never been reported before in this clinical scenario.

DS can no longer be considered a "pediatric" disease; rather, it is a condition that can affect an individual's whole lifespan.

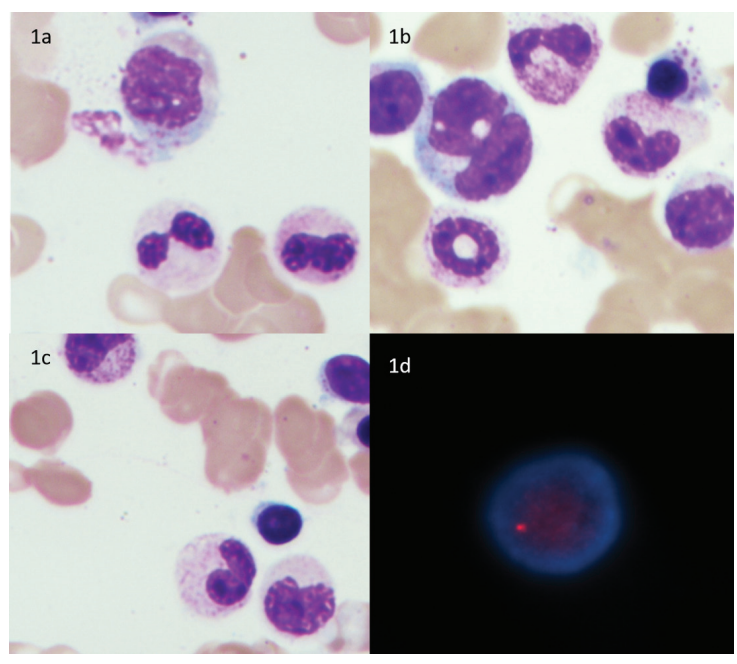

Figure 1. Bone marrow examination revealed significant dysgranulopoiesis in 43\% of neutrophils in the form of hypolobation, hypogranulation, ring forms, and pseudo-PelgerHuet anomaly (a-c), while fluorescence in situ hybridization testing revealed deletion of the $20 q 12$ locus in $140 / 200$ (70\%) of nuclei examined $(d)$. 
Comprehensive research has been done on myeloid neoplasms related to pediatric DS; we now emphasize the importance of reporting similar findings in adult patients, so as to be able to better delineate the course and subsequent management of this under-recognized condition in later life.

Keywords: Adult, Down syndrome, Myelodysplastic syndrome

Anahtar Sözcükler: Yetişkin, Down sendrom, Myelodisplastik sendrom

Informed Consent: Informed consent was obtained from the patient included in the study.

\section{Authorship Contributions}

Data Collection or Processing: H.V.; Literature Search: H.V., S.N.; Writing: H.V., S.N.

Conflict of Interest: We confirm that there are no conflicts of interest to declare.

\section{References}

1. Fong CT, Bordeur GM. Down's syndrome and leukemia: epidemiology, genetics, cytogenetics and mechanisms of leukemogenesis. Cancer Genet Cytogenet 1987;28:55-76.

2. Glasson EJ, Sullivan SG, Hussain R, Petterson BA, Montgomery PD, Bittles AH. The changing survival profile of people with Down's syndrome: implications for genetic counselling. Clin Genet 2002;62:390-393.

3. Carfi A, Antocicco M, Brandi V, Cipriani C, Fiore F, Mascia D, Settanni S, Vetrano DL, Bernabei R, Onder G. Characteristics of adults with Down syndrome: prevalence of age-related conditions. Front Med (Lausanne) 2014;1:51.

4. De Benedittis D, Fianchi L, Niscola P, Piccioni A, Di Veroli A, Campagna A, Mancini S, Villiva N, Mohamed S, Carmosino I, Criscuolo M, Fenu S, Aloe Spiriti MA, Buccisano F, Breccia M, Mancini M, Latagliata R. Myelodysplastic syndromes with isolated 20q deletion: a new clinical-biological entity? Blood 2018;132(Suppl 1):5516.

5. McLean S, McHale C, Enright H. Hematological abnormalities in adult patients with Down's syndrome. Ir J Med Sci 2009;178:35-38.
Address for Correspondence/Yazışma Adresi: Shano Naseem, M.D., Postgraduate Institute of Medical

Education and Research, Department of Hematology, Chandigarh, India

Phone : 91-172-2755131

E-mail : shanonaseem@yahoo.co.in ORCID: orcid.org/0000-0003-0580-019X
Received/Geliș tarihi: November 8, 2019 Accepted/Kabul tarihi: February 13, 2020

DOI: 10.4274/tjh.galenos.2020.2019.0397 